\title{
Performa Keuangan Perusahaan Sub-Sektor terdampak Covid-19
}

\author{
Permata Dian Pratiwi \\ Universitas Ahmad Dahlan, Yogyakarta \\ Adhitya Rechandy Christian \\ Universitas Ahmad Dahlan, Yogyakarta \\ Email:permata.pratiwi@mgm.uad.ac.id
}

\begin{abstract}
Abstrak
Penelitian ini bertujuan untuk mengetahui performa keuangan perusahaan dengan menguji pengaruh struktur aktiva dan pendapatan terhadap hutang, serta pendapatan terhadap laba perusahaan pada sub-sektor yang paling terdampak Covid-19 yang terdaftar di Bursa Efek Indonesia tahun 2020. Teknik pengambilan sampel dengan purposive sampling dengan kriteria tertentu diperoleh sampel sebanyak 82 perusahaan. Hasil penelitian menunjukkan bahwa struktur aktiva pengaruh negatif signfikan terhadap hutang perusahaan. Hasil lain menunjukkan bahwa pendapatan tidak berpengaruh terhadap hutang maupun laba perusahaan. Sedangkan dilihat dari rata-rata pendapatan dan laba perusahaan cenderung menurun selama pandemic ini. Hal ini mendukung temuan bahwa selama pandemic Covid-19 performa keuangan perusahaan pada sub-sektor yang paling terdampak Covid-19 cenderung menurun.
\end{abstract}

Kata Kunci: struktur aktiva, pendapatan, hutang, laba, perusahaan terdampak Covid-19

\section{Pendahuluan}

Pada akhir tahun 2019, tepatnya di bulan Desember muncul wabah penyakit yang disebabkan oleh virus baru bernama Covid-19 di Wuhan, China. Wabah ini mulai masuk ke wilayah Indonesia pada awal tahun 2020 dan diumumkan penderita pertama pada bulan Maret 2020. Wabah ini telah dikategorikan sebagai pandemi oleh Organisasi Kesehatan Dunia (WHO, 2019) dengan ditunjukkan peningkatan infeksi antar individu manusia, yang menyebabkan lebih dari 200.000 kematian dalam waktu tiga bulan sejak dimulainya wabah (World Health Organisation 2020).

Berada di tengah pandemi Covid-19 global ini menimbulkan dua jenis krisis di negaranegara, yaitu kesehatan dan perkenomian (Dev, Mahendra dan Sengupta, 2020). Tahun 2020 ini menjadi tahun yang cukup berat bagi masyarakat dunia dengan adanya virus tersebut. Semua aktivitas terbatas, baik aktivitas individu maupun perusahaan. Selain berdampak negatif bagi pendapatan masyarakat, pandemi Covid-19 ini juga menurunkan performa perusahaan, baik perusahaan kecil seperti UMKM maupun perusahaan besar yang sudah go public. Performa perusahaan dapat dilihat dari laporan keuangan yang diterbitkan oleh perusahaanperusahaan tersebut.

Pembatasan aktivitas baik individu atau perusahaan selama pandemi ini berdampak pada kinerja perusahaan di Indonesia. Sektor yang paling terdampak adalah sektor energi, pariwisata terutama perhotelan dan penerbangan, serta sektor infrastruktur transportasi seperti Jasamarga dan Waskita (Suara.com. 2020). Sedangkan menurut sumber lain, industri yang paling terdampak Covid-19 adalah perhotelan, penerbangan, properti, mall dan agen travel. 
Selain sektor tersebut, industri tekstil, manufaktur otomotif, dan supplier otomotif juga menurun kinerjanya selama pandemi (Medcom.id. 2020).

Kinerja perusahaan yang menurun dapat dicerminkan dari lemahnya pendapatan yang berdampak pada menurunnya laba perusahaan. Menghasilkan laba merupakan tujuan klasik yang utama bagi setiap perusahaan. Di masa pandemi dimana aktivitas perusahaan dan masyarakat dibatasi tentunya sangat berdampak pada kegiatan operasional perusahaan. Perusahaan tidak dapat beroperasi secara normal sehingga target pendapatan dan laba yang sudah ditetapkan pun kemungkinan besar tidak dapat tercapai. Untuk menjaga keberlangsungan perusahaan, stakeholder internal perusahaan harus siap dan cepat merespon perubahan kebijakan yang dibuat baik oleh pemerintah Indonesia, luar negeri maupun dunia. Pembatasan aktivitas ini paling berdampak sektor pariwisata, perhotelan dan penerbangan. Pemerintah dalam dan luar negeri membatasi mobilitas masyarakat, terutama yang tidak urgent. Mereka juga menghimbau masyarakat untuk tetap di rumah saja kecuali ada hal yang penting dan mendesak untuk keluar rumah. Selain menghimbau masyarakat, destinasi wisata di Indonesia juga banyak yang ditutup sesuai dengan peraturan pemerintan baik pusat maupun daerah selama pandemi ini. Jika wisata menurun tentunya akan berdampak pada menurunnya kinerja sektor perhotelan.

Perusahaan-perusahaan yang terkena dampak pandemi Covid-19 cenderung mengalami penurunan pendapatan. Pembatasan aktivitas mengakibatkan permintaan konsumen akan produk baik barang dan jasa menurun. Penurunan permintaan konsumen ini mengakibatkan pendapatan perusahaan menurun. Pendapatan perusahaan yang menurun cenderung akan menurunkan laba perusahaan juga. Laba merupaka tujuan utama perusahaan, tetapi laba tidak akan tercapai jika sumber daya juga tidak terpenuhi. Sumber daya perusahaan salah satunya adalah sumber daya manusia atau karyawan. Beberapa perusahaan terpaksa mengurangi jumlah karyawan selama sejak awal pandemi karena tidak mampu membayarkan gaji karyawannya. Selain sumber daya manusia, perusahaan juga memiliki beban lain seperti hutang. Perusahaan yang memiliki asset tinggi terutama asset tetapnya, masih dapat menggunakannya sebagai collateral atau jaminan jika kondisi keuangannya menurun dengan ditunjukkan menurunnya laba perusahaan. Aktiva tetap yang digunakan sebagai jaminan dapat mengurangi risiko kreditor apabila perusahaan tidak mampu melunasi kewajibannya maka aktiva tersebut akan diambilalih dan dijual oleh kreditor sebagai bentuk pelunasan (Steven dan Lina 2011)

Banyak perusahaan yang mengalami masalah keuangan saat pandemi Covid-19 ini dan mengatasinya dengan menambah hutang baru. Perusahaan dengan asset tetap tinggi akan memiliki jaminan dan kesempatan untuk menambah hutang (Brigham dan Ehrhardt 2011). Penambahan hutang ini biasanya akan menurunkan laba perusahaan karena harus membayar beban pinjaman dan bunga. Kebijakan pendanaan perusahaan melalui hutang diarahkan agar tujuan perusahaan tercapai. Perusahaan yang mengalami financial distress membutuhkan pendanaan, salah satunya dari hutang ini agar tetap bertahan. Perusahaan yang bertahan akan mampu menghasilkan pendapatan sesuai target. Setiap kebijakan yang diambil perusahaan akan mempengaruhi kebijakan lainnya dan memiliki efek domino. Sedangkan pada beberapa perusahaan saat tingkat pertumbuhan penjualan positif, perusahaan akan cenderung mengambil hutang agar dapat meningkatkan kapasitas produksi dan penjualannya. Meningkatkan kapasitas produksi dan penjualan dengan pengadaan mesin produksi baru dan memperluas jaringan pemasaran membutuhkan biaya yang cukup besar (Priambodo et al. 2014). Hal tersebut yang membuat tingkat pertumbuhan pendapatan berpengaruh positif terhadap penambahan hutang. Hutang tersebut diharapkan dapat dibayar dari laba yang didapatkan perusahaan dari peningkatan pertumbuhan pendapatan. Dalam kondisi menghadapi permsalahan pandemic Covid-19, banyak perusahaan cenderung memiloh bertahan daripada berkembang. Sehingga 
perusahaan cenderung menahan untuk menambah hutang dan menggunakan aktiva tetap yang ada untuk operasional meskipun penjualan dapat meningkat. Dengan adanya perbedaan konsep dan kebijakan dalam menentukan performa keuangan perusahaan, maka penulis tertarik untuk menganalisis struktur aktiva, pendapatan, laba dan hutang perusahaan - perusahaan di sektor terdampak covid-19 yang terdaftar di Bursa Efek Indonesia tahun 2020.

\section{Landasan Teori dan Pengembangan Hipotesis}

\section{A. Pandemi Covid-19}

Corona virus atau yang biasa dikenal dengan nama Covid-19 merupakan penyakit infeksi yang disebabkan oleh virus korona (World Health Organisation 2020). Virus ini pertama kali terjadi dan ditemukan di daerah Wuhan (China) pada akhir tahun 2019. Pada tanggal 20 Maret 2020, Presiden Joko Widodo mengumumkan pertama kalinya bahwa ada warga negara Indonesia yang terkonfirmasi positif Covid-19. Virus korona menyebar hampir di sleuruh dunia, dari negara-negara di Asia, Eropa, Australia dan Amerika, sehingga oleh Organisasi Kesehatan Dunia virus ini dikategorikan sebagai wabah atau pandemi. Untuk mengurangi tingkat penyebaran virus ini, pemerintah dan organisasi kesehatan menghimbau untuk mengikuti protokol kesehatan, seperti mencuci tangan, memakai masker dan menjaga jarak. Pemerintah Indonesia baik pemerintah daerah maupun pusat beberapa kali mengelurkan peraturan pembatasan mobilitas. Pembatasan mobilitas ini sangat berdampak pada perekonomian baik mikro maupun makro.

\section{B. Struktur Aktiva}

Struktur aktiva adalah kekayaan atau sumber-sumber ekonomi yang dimiliki oleh perusahaan yang diharapkan akan memberikan manfaat dimasa yang akan datang yang terdiri dari aktiva tetap, aktiva tidak berwujud, aktiva lancar, dan aktiva tidak lancar (Titman et al. 1988). Struktur aktiva adalah sebuah jaminan perusahaan yang asetnya memadai untuk digunakan sebagai jaminan dalam menggunakan hutang. Aset umum yang dapat digunakan oleh banyak perusahaan dapat menjadi jaminan yang baik, sementara tidak untuk aset dengan tujuan khusus. Perbandingan antara aktiva tetap terhadap total aktiva adalah struktur aktiva (Sudana 2015). Struktur aktiva diharapkan berpengaruh positif dan signifikan terhadap penambahan hutang. Sesuai dengan hasil penelitian terdahulu, struktur aktiva berpengaruh positif dan signifikan terhadap struktur modal (Indrajaya et al. 2011).

\section{Pendapatan}

Pendapatan perusahaan dapat diperoleh dari penjualan produk perusahaan atau juga dari investasi yang dilakukan perusahaan. Penjualan adalah proses sosial yang di dalamnya individu dan kelompok mendapatkan apa yang mereka butuhkan dan inginkan dengan menciptakan dan menawarkan produk yang bernilai secara bebas dengan pihak lain (Kotler dan Keller 2016). Penjualan adalah persetujuan kedua belah pihak antara penjual dan pembeli, di mana penjual menawarkan suatu produk dengan harapan pembeli dapat memberikan sejumlah uang sebagai alat tukar produk tersebut, sebesar harga jual yang disepakati (Putra 2014). Penjualan adalah suatu kegiatan transaksi yang dilakukan untuk mendapatkan keuntungan (Priambodo 2014). Sebuah perusahaan yang penjualannya relatif stabil akan aman dalam mengambil lebih banyak hutang dan menanggung beban tetap yang lebih tinggi daripada perusahaan yang penjualannya tidak stabil (Brigham dan Houston 2004). 


\section{Permata Dian Pratiwi, Adhitya Rechandy Christian}

\section{Hutang Perusahaan}

Hutang merupakan sumber pendanaan eksternal atau modal perusahaan dalam memulai atau mendukung keberlangsungan operasional perusahaan. Kebijakan pendanaan perusahaan, khususnya penggunaan hutang tergantung perusahaan dalam menentukan komposisi struktur modalnya. Struktur modal adalah perimbangan antara modal asing atau utang dengan modal sendiri(Brigham dan Houston 2004). Pemilik perusahaan atau investor lebih menyukai perusahaan menggunakan hutang pada tingkat tertentu dengan harapan kesejahteraan mereka tercapai. Teori trade-off menyatakan bahwa rasio hutang yang optimal ditentukan berdasarkan pada perbandingan antara manfaat dan biaya yang timbul akibat penggunaan hutang. Faktorfaktor yang perlu dipertimbangkan perusahaan ketika membuat keputusan struktur modal adalah stabilitas penjualan, struktur aktiva, tingkat pertumbuhan, profitablitas, pajak, pengendalian, sikap manajemen, sikap pemberi pinjaman dan agen pemberi peringkat, kondisi pasar, kondisi internal perusahaan, fleksibilitas keuangan (Brigham dan Houston 2004). Sedangkan menurut teori pecking order, perusahaan cenderung menggunakan dana internal terlebih dahulu untuk operasional perusahaan. Jika dana internal tidak mencukupi, alternatif pendanaan selanjutnya adalah menggunakan dana eksternal seperti hutang.

\section{E. Laba Perusahaan}

Laba merupakan suatu ukuran keseluruhan prestasi dari sebuah perusahaan yang didefinisikan dari selisih antara penjualan dan biaya (Hanafi 2004). Terdapat beberapa jenis laba yang dihasilkan oleh perusahaan, seperti laba operasi, laba sebelum pajak dan laba bersih. Laba operasi merupakan selisih antara penjualan perusahaan dan biaya-biaya operasioanl yang dikeluarkan oleh perusahaan. Laba sebelum pajak adalah laba operasional dikurangi beban bunga. Sedangkan laba bersih adalah selisih antara laba sebelum pajak dan pembayaran pajak.

\section{F. Pengembangan Hipotesis}

Perusahaan yang mempunyai aktiva tetap lebih besar daripada aktiva lancar cenderung akan menggunakan utang lebih besar karena aktiva tersebut bisa dijadikan jaminan hutang. Dalam meningkatkan produktivitas, perusahaan manufaktur cenderung meningkatkan aktiva tetap. Penambahan aktiva tetap dalam perusahaan membutuhkan banyak biaya sehingga mendorong perusahaan untuk menambah hutang. Meskipun hal tersebut membuat nilai struktur modal bertambah, akan tetapi penambahan aktiva tetap diharap dapat meningkatkan produktivitas perusahaan dalam menghasilkan barang produksi untuk dijual dan menghasilkan keuntungan bagi perusahaan (Brigham dan Ehrhardt 2011. Perusahaan dengan struktur aktiva yang tinggi cenderung memilih menggunakan dana dari pihak luar atau hutang untuk mendanai kebutuhan modalnya. Semakin banyak aset suatu perusahaan berarti semakin banyak collateral assets untuk bisa mendapat sumber dana eksternal berupa hutang (Sansoethan dan Suryono 2016). Hasil penelitian Akinyomi dan Olagonju (2013) menunjukkan bahwa struktur aktiva berpengaruh posititif terhadap struktur modal. Berdasarkan penjelasan tersebut maka dibuat hipotesis sebagai berikut :

$\boldsymbol{H}_{1}$ : $\quad$ Struktur aktiva berpengaruh positif signifikan terhadap hutang perusahaan.

Pertumbuhan pendapatan dari penjualan memiliki pengaruh signifikan terhadap penambahan hutang dikarenakan meningkatnya pertumbuhan penjualan mendorong manajemen untuk menggunakan atau menambah hutang. Menambahan hutang ini dapat dipandang sebagai meningkatnya kepercayaan masyarakat, khususnya investor terhadap perusahaan. Meskipun konsekuensi dari penambahan hutang adalah peningkatan risiko bagi perusahaan, namun investor percaya bahwa manajemen akan mampu mengelola hutang tersebut dengan baik, sehingga dampak penggunakan hutang atau peningkatan risiko tidak 
membawa efek negatif bagi perusahaan (Eviani, 2015). Hasil penelitian Mahapsari et al. (2013) menunjukkan bahwa penjualan berpengaruh positif dan signifikan secara statistik terhadap struktur modal. Hasil penelitian tersebut sesuai dengan konsep dari asimetris informasi dan signaling theory. Dapat diartikan juga bahwa penambahan pendapatan berpengaruh positif terhadap penambahan hutang (Suweta et al. 2016). Dalam kondisi pandemic Covid-19 perusahaan cenderung mengalami ketidakpastian sehingga perusahaan akan memilih menggunakan dana internal yang risikonya lebih rendah daripada hutang eksternal sesuai teori pecking order. Maka hipotesis yang terbentuk dalam penelitian ini adalah: $\boldsymbol{H}_{2}$ : $\quad$ Pendapatan berpengaruh negatif signifikan terhadap hutang perusahaan.

Pertumbuhan penjualan merupakan indikator penting dari penerimaan produk perusahaan oleh konsumen. Peningkatan pendapatan diharapkan dapat meningkatkan laba perusahaan. Hasil penelitian Putranto (2017) menunjukkan terdapat pengaruh positif penjualan terhadap laba perusahaan. Sedangkan hasil penelitian Zahara dan Zannati (2018) menunjukkan penjualan tidak berpengaruh terhadap laba bersih. Sesuai hasil penelitian Rustami et al. (2014) yang menyatakan bahwa terdapat pengaruh positif secara parsial antara volume penjualan terhadap laba, maka hipotesis yang terbentuk dalam penelitian ini sebagai berikut:

$\boldsymbol{H}_{3}$ : $\quad$ Pendapatan berpengaruh positif signifikan terhadap laba perusahaan.

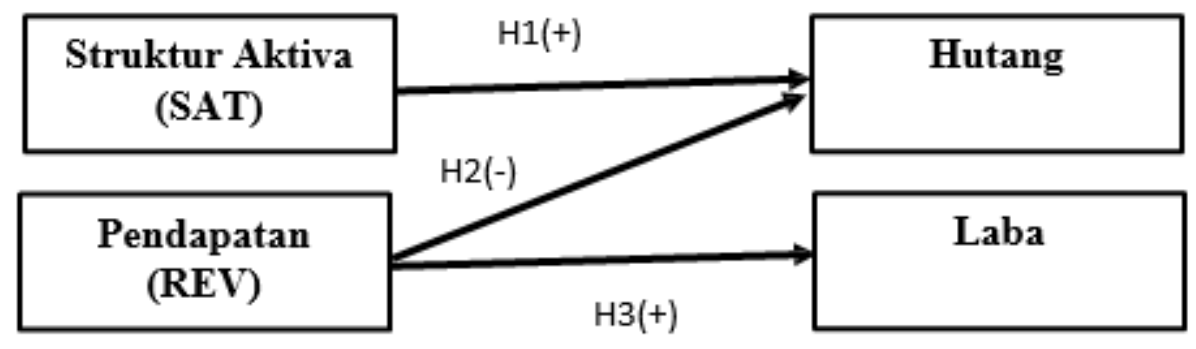

\section{Gambar 1. Model Penelitian}

\section{Metode Penelitian}

Metode penelitian ini meliputi desain penelitian, jenis dan sumber data, populasi dan sampel, metode pengumpulan data, definisi operasional variabel, uji asumsi klasik, dan metode analisis data. Desain penelitian yang digunakan dalam penelitian ini adalah desain penelitian kuantitatif. Penelitian ini dilakukan dengan cara mengumpulkan dan mengolah data sekunder yang bersumber dari laporan keuangan perusahaan sampel Jenis data yang digunakan dalam penelitian ini bersifat cross-sectional, yaitu jenis data yang dikumpulkan pada suatu waktu untuk menjelaskan fenomena pada objek penelitian. Jenis data yang digunakan dalam penelitian ini adalah data sekunder.

Populasi dalam penelitian ini adalah seluruh perusahaan pada sektor atau sub-sektor yang paling terdampak Covid-19 yang terdaftar di Bursa Efek Indonesia (BEI) pada tahun 2020. Populasi penelitian ini adalah 17 perusahaan yang masuk dalam sub-sektor logam, 9 perusahaan yang masuk dalam sub-sektor pertambangan minyak dan gas bumi, 13 perusahaan yang masuk dalam sub-sektor otomotif dan komponen, 21 perusahaan yang masuk dalam subsektor tekstil dan garmen, 65 perusahaan yang masuk dalam sub-sektor property dan real estate, 18 perusahaan yang masuk dalam sub-sektor konstruksi dan bangunan, 8 perusahaan yang masuk dalam sub-sektor energi, 5 perusahaan yang masuk dalam sub-sektor jalan tol, bandara, pelabuhan dan sejenisnya, 46 perusahaan yang masuk dalam sub-sektor transportasi, 35 


\section{Permata Dian Pratiwi, Adhitya Rechandy Christian}

perusahaan yang masuk dalam sub-sektor hotel, restoran dan pariwisata. Jumlah populasi dalam penelitian ini sebanyak 237 perusahaan. Teknik pengambilan sampel dalam penelitian ini menggunakan metode purposive sampling, dimana kriteria perusahaan populasi yang memiliki data laporan keuangan yang lengkap di Bursa Efek Indonesia pada periode penelitian 2019 dan 2020. Setelah dilakukan teknik pengambilan sampel dengan metode purposive sampling, maka sampel yang digunakan dalam penelitian ini sebanyak 82 perusahaan.

Dalam penelitian ini terdapat 2 variabel utama penelitian, yaitu variabel dependen dan variabel independen. Variabel dependen dalam penelitian ini adalah hutang dan laba, sementara variabel independennya yaitu struktur aktiva (SAT) dan pendapatan (REV). Pengukuran untuk semua variabel dalam penelitian ini menggunakan rasio yang diperoleh dari selisih antara data tahun $\mathrm{t}$ dan $\mathrm{t}-1$ dibagi dengan $\mathrm{t}-1$. Data hutang perusahaan diperoleh dari selisih hutang perusahaan pada tahun t dan t-1 dibagi t-1. Data laba perusahaan diperoleh dari selisih laba bersih perusahaan pada tahun $\mathrm{t}$ dan t-1 dibagi t-1 (Harahap, 2018). Data struktur aktiva diperoleh dari selisih rasio aktiva tetap dibagi total aktiva pada tahun $\mathrm{t}$ dan $\mathrm{t}-1$ dibagi $\mathrm{t}-1$. Data pendapatan perusahaan diperoleh dari selisih pendapatan atau penjualan perusahaan pada tahun $\mathrm{t}$ dan $\mathrm{t}-1$ dibagi $\mathrm{t}-1$.

Untuk memperoleh estimasi regresi yang baik, sampel akan diuji terlebih dahulu, guna menghindari adanya penyimpangan asumsi klasik. Uji yang dilakukan meliputi uji multikolinearitas, uji autokorelasi, dan uji heteroskedastisitas. Uji normalitas dilakukan untuk megetahui apakah distribusi sebuah data mengikuti atau mendekati distribusi normal, yaitu distribusi yang mempunyai pola distribusi normal. Data dapat dikatakan terdistribusi secara normal apabila data memusat pada nilai rata-rata dan median. Untuk menguji normalitas, penelitian ini menggunakan uji Jarque-Berra.

Uji selanjutnya adalah pengujian multikolinearitas yang merupakan kondisi dimana terdapat hubungan linear antar variabel independen (Gujarati 2003). Salah satu cara guna mendeteksi multikolinearitas adalah dengan melihat korelasi antar variabel. Jika korelasi antar variabel kurang dari 0,9 maka dapat diartikan bawah variabel independen tidak saling memiliki hubungan linier. Uji asumsi klasik berikutnya adalah autokorelasi, yang merupakan suatu hubungan atau korelasi antara anggota observasi dalam suatu kurun waktu apabila datanya merupakan data time series dan dalam suatu ruang apabila datanya merupakan data cross section (Gujarati 2003). Untuk mendekteksi adanya penyimpangan asumsi autokorelasi dapat dilakukan dengan menggunakan metode Bruesch-Godfrey. Uji asumsi klasik yang terakhir adalah mendeteksi adanya penyakit heteroskedastisitas, yang berarti terdapat hubungan antara error term dengan variabel independen. Varians error term akan berubah seiring dengan perubahan pada variabel independen (varians error term tidak konstan). Pada penelitian ini untuk menguji ada tidaknya heteroskedastisitas digunakan uji White.

Untuk menguji pengaruh struktur aktiva dan pendapatan terhadap hutang dan laba, peneliti mengembangkan persamaan regresi dalam penelitian ini sebagai berikut.

$$
\begin{array}{ll}
\text { Hutang }_{i} & =\beta_{1}+\beta_{2} \mathbf{S A T}_{i}+\beta_{3} \mathbf{R E V}_{i}+\varepsilon_{i} \\
\text { Laba }_{i} & =\beta_{4}+\beta_{5} \mathbf{R E V}_{i}+\varepsilon_{i}
\end{array}
$$

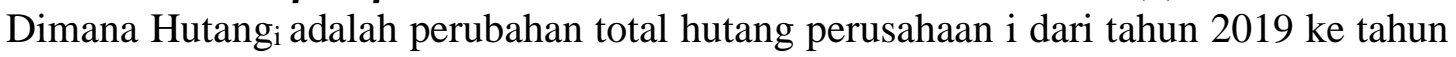
2020, Laba $_{\mathrm{i}}$ adalah perubahan laba bersih perusahaan $\mathrm{i}, \mathrm{SAT}_{\mathrm{i}}$ adalah struktur aktiva perusahaan i dengan menggunakan perubahan aktiva tetap dibagi total aktiva dari tahun 2019 ke tahun $2020, \mathrm{REV}_{\mathrm{it}}$ adalah perubahan pendapatan perusahaan i, dan $\varepsilon_{\mathrm{i}}$ adalah error term. Pengujian hipotesis akan dilakukan dengan menggunakan uji-t yang merupakan pengujian parsial. 


\section{Pembahasan}

Sampel penelitian ini berjumlah 82 pada sektor atau sub-sektor yang paling terdampak Covid-19 yang terdaftar di Bursa Efek Indonesia (BEI) pada tahun 2020. Tabel 1 berisi mengenai analisis statistik deskriptif dari data penelitian.

Tabel 1. Statistik Deskriptif

\begin{tabular}{|l|l|r|r|r|c|}
\hline \multicolumn{1}{|c|}{ Variabel } & N & Minimum & Maksimum & Rata-rata & Standar Deviasi \\
\hline Hutang & 82 & $-0,979$ & 0,731 & $-0,026$ & 0,279 \\
\hline Laba & 82 & $-10,580$ & 48,522 & $-0,151$ & 6,662 \\
\hline Struktur Aktiva & 82 & $-0,451$ & 2,019 & 0,042 & 0,295 \\
\hline Pendapatan & 82 & $-0,893$ & 2,403 & $-0,207$ & 0,378 \\
\hline
\end{tabular}

Sumber data diolah, 2021

Tabel 1 menunjukkan bahwa rata-rata hampir semua variabel bernilai negatif, kecuali struktur aktiva.yang memiliki rata-rata sebesar 0,042. Pada tahun 2020, perusahaan yang terdampak Covid-19 cenderung tidak menambah hutangnya karena ketidakpastian kondisi makro maupun mikro. Tabel 1 juga menunjukkan bahwa laba dan pendapatan perusahaan cenderung menurun selama pandemi Covid-19.

Tabel 2. Uji Asumsi Klasik

\begin{tabular}{|l|l|c|c|}
\hline \multicolumn{1}{|c|}{ Uji asumsi klasik } & \multicolumn{1}{c|}{ Metode } & Eq. 1 & Eq. 2 \\
\hline Normalitas & Jarque - Bera & 25,665 & 4576,132 \\
\hline Multikolinieritas & Korelasi REV dan SAT & $-0,367$ & - \\
\hline Autokorelasi & Breuch Godfrey & 0,4026 & 0,9460 \\
\hline Heteroskedastisitas & White & 0,6381 & 0,4337 \\
\hline
\end{tabular}

Sumber data diolah, 2021

Pengujian asumsi klasik untuk kedua model penelitian ditunjukkan pada tabel 2. Kedua model penelitian memiliki data yang tidak berdistribusi normal. Data yang tidak normal selama masa pandemi Covid-19 umum terjadi karena penyebaran data yang cukup bervariasi. Dalam kondisi pandemic, perusahaan ada yang dapat bertahan ada juga yang menurun kinerjanya meskipun dalam satu sub sektor. Selain itu, kedua model persamaan regresi dalam penelitian ini terbebas dari masalah asumsi klasik, sehingga dapat dilanjutkan pengujian hipotesis.

Tabel 3. Pengujian Hipotesis

\begin{tabular}{|l|c|c|c|c|}
\hline & C & REV & SAT & $\mathbf{R}^{\mathbf{2}}$ \\
\hline Hutang & $-0,028$ & $-0,087$ & $-0,366^{* * * *}$ & 0,130 \\
\hline Koefisien & $-0,857$ & $-1,043$ & $-3,428$ & \\
\hline $\mathrm{t}$ & 0,220 & 1,787 & & 0,010 \\
\hline Laba & 0,261 & 0,912 & & \\
\hline Koefisien & $\mathrm{t}$
\end{tabular}

Sumber data diolah, 2021. *** menunjukkan signifikan pada level $1 \%$. 


\section{Permata Dian Pratiwi, Adhitya Rechandy Christian}

Perusahaan dengan struktur aktiva yang tinggi cenderung memilih menggunakan dana dari pihak luar atau hutang untuk mendanai kebutuhan modalnya ${ }^{15}$. Aktiva tetap biasanya digunakan sebagai jaminan tetapi jika biaya hutang sudah terlalu tinggi maka perusahaan sebaiknya tidak menambah hutang lagi agar tidak terhindar dari risiko yang tidak diinginkan. Kondisi ini sejalan dengan hasil penelitian ini dan penelitian Andika dan Fitria (2016) yang menunjukkan bahwa struktur aktiva bepengaruh negatif signifikan terhadap hutang perusahaan. Struktur aktiva tetap yang tinggi tidak membuat perusahaan untuk menambah hutang selama pandemi Covid-19. Perusahaan cenderung menahan untuk menambah hutang meskipun kondisi penjualan kurang baik. Karena menambah hutang perusahaan akan menambah risiko perusahaan juga dimasa pandemic Covid-19. Perusahaan menimbang tradeoff antara manfaat dan risiko penggunaan hutang selama pandemic berbeda dengan kondisi sebelu pandemic Covid-19.

Hasil pengujian hipotesis pada tabel 3 menunjukkan bahwa pendapatan perusahaan tidak berpengaruh negatif signifikan terhadap hutang perusahaan terdampak Covid-19 yang terdaftar di Bursa Efek Indonesia (BEI) pada tahun 2020. Hasil penelitian ini menunjukkan bahwa hipotesis 2 tidak diterima. Menurut Brigham dan Houston (2004) sebuah perusahaan yang penjualannya relatif stabil akan aman dalam mengambil lebih banyak hutang dan menanggung beban tetap yang lebih tinggi daripada perusahaan yang penjualannya tidak stabil. Tetapi dalam ketidakpastian selama pandemic Covid-19, penambahan pendapatan dari penjualan tidak membuat hutang perusahaan juga bertambah, sesuai dengan yang dikemukakan teori pecking order. Begitu juga bagi perusahaan yang mengalami penurunan pendapatan juga cenderung tidak berani menambah hutang karena akan meningkatkan risiko kebangkrutan perusahaan.

Hipotesis ketiga penelitian ini menyatakan bahwa pendapatan perusahaan berpengaruh positif terhadap laba perusahaan selama pandemic Covid-19. Dalam pengujian hipotesis pada tabel 3 menunjukkan bahwa pendapatan perusahaan berpengaruh positif tetapi tidak signifikan terhadap laba perusahaan yang artinya hipotesis 3 tidak diterima. Secara konsep, peningkatan pendapatan akan meningkatkan laba perusahaan. Selama pandemic Covid-19 ini, banyak perusahaan yang mengalami kerugian karena penurunan tingkat penjualan dibandingkan sebelum pandemic Covid-19 pada tahun 2019. Hasil ini sejalan dengan penelitian yang dilakukan oleh Zahara dan Zannati (2018).

\section{Kesimpulan}

Pandemic Covid-19 membuat kondisi perekonomian Indonesia baik makro maupun mikro mengalami penurunan performa. Hasil penelitian ini menunjukkan bahwa struktur aktiva yang baik tidak membuat perusahaan menambah hutangnya selama pandemic Covid-19. Pendapatan perusahaan juga tidak mempengaruhi hutang perusahaan. Selain itu, perusahaan mengalami penurunan pendapatan sehingga laba perusahaan juga menurun. Performa keuangan perusahaan selama pandemic Covid-19 ini cenderung menurun dilihat dari laba dan penjualan. Saran penelitian selanjutanya lebih memperdalam lagi mengenai analisis keuangan perusahaan selama pandemic dan cara perusahaan mengatasi permasalahan dari pandemic Covid-19.

\section{Daftar Pustaka}

Akinyomi, O.J. dan Olagonju,A. (2013) "Determinants of Capital Structure in Nigeria". International Journal of Innovation and Applied Studies, 3(4). 
Andika, A. P. dan Fitria, A. (2016) "Pengaruh Struktur Aktiva, Ukuran Perusahaan, Profitabilitas dan Risiko Bisnis terhadap Struktur Modal". Jurnal Ilmu dan Riset Akuntansi, 5(9).

Brigham, E. F. dan Ehrhardt. (2011) Financial Management: theory and practice (13 ${ }^{\text {th }}$ Edition). South-Western.

Brigham, E. F. dan Houston, J. F. (2004) Fundamentals of Financial Management. SouthWestern.

Dev, S. Mahendra dan Sengupta, R. (2020) "Impact of Covid-19 on the Indian Economy: An Interim Assessment". Indira Gandhi Institute of Development Research.

Eviani, A. D. (2015) "Pengaruh Struktur Aktiva, Pertumbuhan Penjualan, Dividend Payout Ratio, Likuiditas dan Profitabilitas Terhadap Struktur Modal". Jurnal Akuntansi dan Sistem Teknologi Informasi, 11(2), 194 - 202.

Gujarati, Damodar N. (2003) Basic Econometrics, (4 ${ }^{\text {th }}$ Edition). Singapore: Mc-Graw Hill.

Hanafi, M. M. (2004) Manajemen Keuangan. BPFE, Yogyakarta.

Harahap, S. S. (2018) Analisis Kritis atas Laporan Keuangan. Rajafrafindo Persada.

Indrajaya, G., Herlina, dan Setiadi, R. (2011) "Pengaruh Struktur Aktiva, Ukuran Perusahaan, Tingkat Pertumbuhan, Profitabilitas dan Risiko Bisnis Terhadap Struktur Modal: Studi Empiris Pada Perusahaan Sektor Pertambangan yang Listing di Bursa Efek Indonesia Periode 2004-2007'. Akurat Jurnal Ilmiah Akuntansi, (6).

Kotler, P. and Keller, K. L. (2016) Marketing Management (15 th Edition). Pearson Education. Mahapsari, N.R., dan Taman, A. (2013) "Pengaruh Profitabilitas, Struktur Aktiva, dan Pertumbuhan Penjualan Terhadap Harga Saham dengan Struktur Modal Sebagai Variabel Intervening pada Perusahaan Manufaktur di Bursa Efek Indonesia”. Jurnal Nominal, 2(1).

Medcom.id. (2020) 3 Sektor Ini Paling Terdampak Covid-19. Diakses dari https://www.medcom.id/ekonomi/bisnis/yKXDzE6K-3-sektor-ini-paling-terdampakcovid-19 pada tanggal 8 April 2021.

Putranto, A. (2017) “Analisis Pengaruh Biaya Produksi dan Penjualan Terhadap Laba Perusahaan (Studi Pada Usaha Mikro Kecil dan Menengah di Kecamatan Wonosobo Kabupaten Wonosobo)". Jurnal PPKM III.

Priambodo, T. J., Topowijono, dan Azizah, D. F. (2014) "Pengaruh Struktur Aktiva, Tingkat Pertumbuhan Penjualan dan Profitabilitas Terhadap Struktur Modal (Studi pada perusahaan Tekstil dan Garmen yang listing di BEI periode 2010-2012)”. Jurnal Administrasi Bisnis (JAB), 9(1).

Rustami, P. , Kirya, I K. dan Cipta, W. (2014) "Pengaruh Biaya Produksi, Biaya Promosi, dan Volume Penjualan Terhadap Laba Pada Perusahaan Kopi Bubuk Banyuatis”. e-Journal Bisma Universitas Pendidikan Ganesha Jurusan Manajemen, 2(1).

Sansoethan, D. K., dan B. Suryono. (2016) "Faktor-Faktor yang Mempengaruhi Struktur Modal pada Perusahaan Makanan dan Minuman". Jurnal Ilmu dan Riset Akuntansi, $5(1)$.

Steven dan Lina. (2011) "Faktor-Faktor yang Mempengaruhi Kebijakan Hutang Perusahaan Manufaktur". Jurnal Bisnis dan Akuntansi, 13(3).

Suara.com. (2020) 11 Bisnis yang Paling Parah Terdampak Covid-19. Diakses dari https://www.suara.com/bisnis/2020/05/27/144827/11-bisnis-yang-paling-parahterdampak-covid-19?page=all pada tanggal 8 April 2021 .

Sudana, I. M. (2015). Manajemen Keuangan Perusahaan: Teori dan Praktik (Edisi 2). Jakarta: Erlangga. 
Suweta, N.M.P.D. dan Dewi, M. R. (2016) "Pengaruh Pertumbuhan Penjualan, Struktur Aktiva, Dan Pertumbuhan Aktiva Terhadap Struktur Modal". E-Jurnal Manajemen Unud, 5(8).

Titman, S. dan Wessels, R. (1988) "The Determinants of Capital Structure Choice". The Journal of Finance, 18(1).

World Health Organisation. (2020) Coronavirus disease (Covid-2019) situation reports. Diakses dari https://www.who.int/emergencies/diseases/novel-coronavirus2019/situation-reports/ pada tanggal 8 April 2021.

Zahara, A. dan Zannati, R. (2018) "Pengaruh Total Hutang, Modal Kerja, dan Penjualan Terhadap Laba Bersih Pada Perusahaan Sub Sektor Batu Bara Terdaftar Di BEI". Jurnal Riset Manajemen dan Bisnis (JRMB) Fakultas Ekonomi UNIAT, 3(2). 